\title{
Optimizing Nitrogen Use Efficiency and Maize Yield under Varying Fertilizer Rates in Kenya
}

\author{
Desire Nduwimana ${ }^{1 *}$, Benson Mochoge ${ }^{1}$, Benjamin Danga ${ }^{1}$, Cargele Masso ${ }^{2}$, \\ Sagar Maitra ${ }^{3}$ and Harun Gitari ${ }^{1}$
}

\author{
${ }^{1}$ School of Agriculture and Enterprise Development, Kenyatta University. P.O. Box 43844 00100, Nairobi, Kenya \\ ${ }^{2}$ International Institute of Tropical Agriculture-Cameroon, $1^{\text {st }}$ Main IRAD road, Nkolbisson, P.O. Box 2008 (Messa), \\ Yaoundé, Cameroon \\ ${ }^{3}$ Centurion University of Technology and Management, Odisha, India
}

"Corresponding author: desirenduwimana800@gmail.com

Received: $23-10-2019$

Revised: $14-11-2020$

Accepted: $11-12-2020$

\begin{abstract}
Nitrogen $(\mathrm{N})$ is a paramount macronutrient for plant growth, development and production. This study was carried out to determine the effect of $\mathrm{N}$ fertilizer at different rates on maize crop yield, $\mathrm{N}$ content and $\mathrm{N}$ use efficiency (NUE) in Rongo sub-county (Kambija and Koderobara sites), Western Kenya. The treatments were $\mathrm{N}(\mathrm{CAN})$ at four levels $\left(0,25,50\right.$ and $\left.75 \mathrm{~kg} \mathrm{~N} \mathrm{ha}^{-1}\right)$. In Kambija, maize yield at $50 \mathrm{~kg} \mathrm{~N}$ $\mathrm{ha}^{-1}\left(4.34 \mathrm{t} \mathrm{ha}^{-1}\right)$ was $62 \%$ higher than the control while in Koderobara, the highest yield $\left(3.41 \mathrm{t} \mathrm{ha}^{-1}\right)$ was recorded at $50 \mathrm{~kg} \mathrm{~N} \mathrm{ha}^{-1}$ and it was $74 \%$ higher than in the control. The highest $\mathrm{N}$ content of 21 and $20 \mathrm{~g}$ $\mathrm{kg}^{-1}$ werenoted at heading growth stage in Kambija and Koderobara, respectively. Generally, partial factor productivity (PFP), partial nitrogen balance (PNB), agronomic $\mathrm{N}$ efficiency (N-AE), and nitrogen fertilizer recover (NFR) decreased with increasing $\mathrm{N}$ application across the sites. The yields exhibited strong relationship with $\mathrm{N}$ uptake in the plant tissues especially at harvest, with coefficient of determination ranging between 0.72 and 0.92 . The study therefore has showed that application of $\mathrm{N}$ at $50 \mathrm{~kg} \mathrm{~N}^{-1}$ was the most viable hence such information needs to be disseminated to farmers.
\end{abstract}

Keywords: Nitrogen use efficiency, Maize yield, Nitrogen fertilizer

Maize (Zea mays L.) is the third high potential yielding cereal crop in the world. It plays a significant role in sub-Sahara Africa (SSA) countries where food nutrition demand is high and population is increasing exponentially (Adenle et al. 2018). Among the agricultural crops, maize is the most cultivated one as it has good nutritive value with $72 \%$ starch, $10 \%$ protein, $4.8 \%$ oil, $8.5 \%$ fiber, $3 \%$ sugar and $17 \%$ ash (Lásztity, 1998). However, scarcity of arable lands (where most farmers own $<1$ ha) and low maize production (roughly estimated at 0.8-1.4 tha$\left.{ }^{1}\right)$ are the key challenges facing smallholder farmers in Kenya (Van Ittersum et al. 2016). Low soil fertility and land degradation contributes negatively to plant growth, hence, threatening smallholder crop production (Sanchez 2002; Gitari et al. 2015, 2019;
Hassan et al. 2020; Maitra et al. 2021; Nyawade et al. 2019). In this perspective, to increase maize yields, farmers are called to apply nitrogen fertilizer given that it is the most limiting macronutrient in western Kenya. Unfortunately, only $16 \%$ of smallholder farmers in Rongo use inorganic fertilizer (Rao et al. 2015). Mineral nitrogen (N) is rapidly available for plant uptake particularly when applied in nitrate $\left(\mathrm{NO}_{3}{ }^{-}\right.$) form (Hodge et al. 2000). Nitrogen needs to be applied in a split manner to create a balance between maize $\mathrm{N}$ demand and $\mathrm{N}$ supply (Fageria et al. 2005).

How to cite this article: Nduwimana, D., Mochoge, B., Danga, B., Masso, C., Maitra, S. and Gitari, H. (2020). Optimizing Nitrogen Use Efficiency and Maize Yield under Varying Fertilizer Rates in Kenya. International Journal of Bioresource Science, 7(2): 63-73.

Source of Support: None; Conflict of Interest: None 9 
Therefore, in particular, soil types such as Nitisols and Ferralsols where $\mathrm{N}$ use deficiencies are high, other sources of $\mathrm{N}$ supply might be used to assure nutrients balances (Roy et al. 2006; Gitari et al. 2018; Nyawade et al. 2020). These sources of $N$ supply comprise $\mathrm{N}$ fertilizer application, previous maize crop residues and soil $\mathrm{N}$ supply. Nitrogen is a principal component of plant protein and nucleic acid hence low $\mathrm{N}$ physiologically affects maize growth and yield. Maize yield increases with increasing $\mathrm{N}$ application rates (Nunes et al. 1996). Applied $\mathrm{N}$ fertilizer has a significant effect on nitrogen uptake at different maize growth stages: tasseling, grain filling and maturity (Ali et al. 2002). Therefore, this study aimed at assessing maize grain yields, $\mathrm{N}$ content and its use efficiency under varying $\mathrm{N}$ fertilizer rates. As a result, there will be an improvement of the production technology due to this major soil nutrient in achieving higher maize grain yield.

\section{MATERIALS AND METHODS}

\section{Site description}

This study was undertaken during the 2018 long rains season in Rongo sub-county, Migori County, Western Kenya and comprised two sites: Kambija, which lies at $0^{\circ} 44^{\prime} 24^{\prime \prime} \mathrm{S}$ and $34^{\circ} 36^{\prime} 00^{\prime \prime} \mathrm{E}$ and Koderobara located at $0^{\circ} 46^{\prime} 48^{\prime \prime} \mathrm{S}$ and $34^{\circ} 36^{\prime} 36^{\prime \prime}$ E. Rongo sub-county inherits much of its climate conditions from the Lake Victoria in the West and the highlands of Kisii county in the East. This location experiences a bimodal rainfall type with long rains (LR) beginning from March to July and short rains (SR) from September to December (Midega et al. 2015). Average annual rainfall ranges from $1400 \mathrm{~mm}$ to $1800 \mathrm{~mm}$ that is the optimal threshold for maize growth (Onyango, 2016). The soils are well-drained with textures of sandy clay loam, clay and sandy clay (Table 1). The soil types include Humisols, Luvisols, and Cambisols (Wischmeier and Mannering, 1969).

\section{Experimental design and crop establishment}

The experiment was set up at two smallholder farmers' fields: at Kambija and Koderobara in Rongo sub-county. Prior to establishment of this experiment Kambija sites was planted with maize and beans whereas Koderobara was under a mono- cropping of maize. The treatments comprising calcium ammonium nitrate (CAN: $26 \% \mathrm{~N})$ fertilizer applied at four levels $(0,25,50$ and $75 \mathrm{~kg} \mathrm{~N}$ ha $\left.{ }^{1}\right)$ were arranged in randomized complete block design with three replicates in plots measuring 6 $\mathrm{m} \times 6 \mathrm{~m}$. Triple super-phosphate (TSP: $46 \% \mathrm{P}_{2} \mathrm{O}_{5}$ ) fertilizer $\left(10 \mathrm{~kg} \mathrm{P} \mathrm{ha}{ }^{-1}\right)$ was applied as a blanket to all treatments. Maize (Duma 43), which is a common variety in the area was used as the test crop. Planting was done at the onset of 2018 long rains (March 6, 2018) at a spacing of $0.3 \mathrm{~m}$ within the row and $0.75 \mathrm{~m}$ between rows. Three seeds were planted per hill and thinned to one plant a month after planting to achieve a plant density of 22,222 plants ha ${ }^{-1}$.

\section{Data collection}

Sampling for plant tissues (leaf and stalk) was done at three maize phenological stages: seedling heading and maturity (4, 8 and 16 weeks after planting, respectively) from three randomly selected plants, cut into small pieces and a $500 \mathrm{~g}$ taken for each treatment then put in khaki bags. Harvesting was carried out 16 weeks after planting (WAP) when the crop was at physiological maturity (at moisture content of $12.5 \%$ ) from a central net area of $4.8 \mathrm{~m} \times 4.5 \mathrm{~m}$ per plot. The maize was threshed, mixed thoroughly and a sample of one kilogram was drawn and packaged in labelled khaki bags. Samples were oven dried for $48 \mathrm{~h}$ at $60^{\circ} \mathrm{C}$ for tissue samples and $105{ }^{\circ} \mathrm{C}$ for grain samples. The samples were ground using a mill machine and sieved to pass through a millimetre sieve. The samples were analyzed for total $\mathrm{N}$ content using Kjeldahl method (Bremner, 1996) after being digested for two hour in a mixture of Hydrogen peroxide, Lithium sulfate and Selenium (catalyst) and Sulphuric acid $\left(\mathrm{H}_{2} \mathrm{SO}_{4}\right)$ (Okalebo et al. 2002). The solution was digested by raising temperature progressively in $30 \mathrm{~min}$ of interval from $200^{\circ} \mathrm{C}$ to $250^{\circ} \mathrm{C}$ and $350^{\circ} \mathrm{C}$. The released $\mathrm{NH}_{3}$ gas during distillation was held by boric acid in the conical flask then titrated using $0.01 \mathrm{~N} \mathrm{HCl}$. Nitrogen content was measured by determining the amount of $0.01 \mathrm{~N} \mathrm{HCl}$ consumed during the titration.

Partial factor productivity (PFP), partial nitrogen balance (PNB), agronomic $\mathrm{N}$ efficiency (N-AE) and nitrogen fertilizer recovery (NFR) were computed using equations 1, 2, 3 and 4 respectively (Albert et al. 2012). 


$$
\mathrm{PFP}=\frac{\text { Maize yield }\left(\mathrm{kg} \mathrm{ha}^{-1}\right)}{\text { Applied } \mathrm{N}\left(\mathrm{kg} \mathrm{ha}^{-1}\right)}
$$

$$
\begin{gathered}
\text { Yield in fertilized plot }\left(\mathrm{kg} \mathrm{ha}^{-1}\right) \\
N-A E=\frac{- \text { Yield in unfertilized plot }\left(\mathrm{kg} \mathrm{ha}^{-1}\right)}{\mathrm{N} \text { applied }\left(\mathrm{kg} \mathrm{ha}^{-1}\right)}
\end{gathered}
$$

$$
\mathrm{PNB}=\frac{\mathrm{N} \text { in Grain }\left(\mathrm{kg} \mathrm{ha}^{-1}\right)}{\text { Applied N }\left(\mathrm{kg} \mathrm{ha}^{-1}\right)}
$$

(N uptake plant tissues with $\mathrm{N}(\%)-$

$$
\mathrm{NFR}=\frac{\mathrm{N} \text { uptake plant tissues with no } \mathrm{N}(\%)}{\text { Applied } \mathrm{N} \text { fertilizer }}
$$

\section{Statistical data analysis}

The data: nitrogen uptake, yield, PFP, PNB, N-AE and NFR were analyzed statistically using GenStat software $15^{\text {th }}$ edition. Means were separated using Protected LSD test at $\mathrm{p} \leq 0.05$. Regression analyses were performed to illustrate how total $\mathrm{N}$ content related to maize yields and $\mathrm{N}$ application rates.

\section{RESULTS AND DISCUSSION}

\section{Weather pattern during maize growing period}

Rongo sub-county is characterized by a tropical climate and receives rainfall in most months, with
$1594 \mathrm{~mm}$ of precipitation recorded during the 2018 long rains season (Fig. 1). April recorded the highest rainfall $(240 \mathrm{~mm})$, which coincided with the seeding stage when the maize requires the highest amount of rainfall. The average annual temperatures were $28.1^{\circ} \mathrm{C}$ and $12.9^{\circ} \mathrm{C}$ for maximum and minimum temperatures, respectively.

\section{Soil physico-chemical properties of the experiment site}

Prior to the establishment of the experiment, the sites were previously planted with maize and beans. The soil's mean bulk density was 1.26 and $1.25 \mathrm{~g} \mathrm{~cm}^{3}$ for Kambija and Koderobara respectively, with sand, silt and clay averaged at 36, 17 and $47 \%$ respectively for Kambija and 47, 6 and $47 \%$ for Koderobara (Table 1). Hence, the soils were generally classified as having a sandy clay texture. The soil in Koderobara was more acidic with a mean $\mathrm{pH}$ of 5.5 compared to that in Kambija with $\mathrm{pH}$ of 6.3. The soils in Kambija had less available P (14.5 $\mathrm{mg} \mathrm{kg}^{-1}$ ) when compared with those in Koderobara (16.6 $\mathrm{mg} \mathrm{kg}^{-1}$ ). Exchangeable $\mathrm{Mg}, \mathrm{Ca}, \mathrm{K}$ and $\mathrm{Na}$ were 11.4, 5.7 and $0.7 \mathrm{meq} 100 \mathrm{~g}^{-1}$, respectively for Kambija and 5.4, 2.3, 1.5 and $1.0 \mathrm{meq} 100 \mathrm{~g}^{-1}$ respectively for Koderobara. Generally, $\mathrm{NO}_{3}^{-}-\mathrm{N}$ and $\mathrm{NH}_{4}{ }^{+} \mathrm{N}$ decreased with increasing depth with mean values of 7.8 and 1.2, respectively in Kambija and 8.2 and 1.0, respectively in Koderobara.

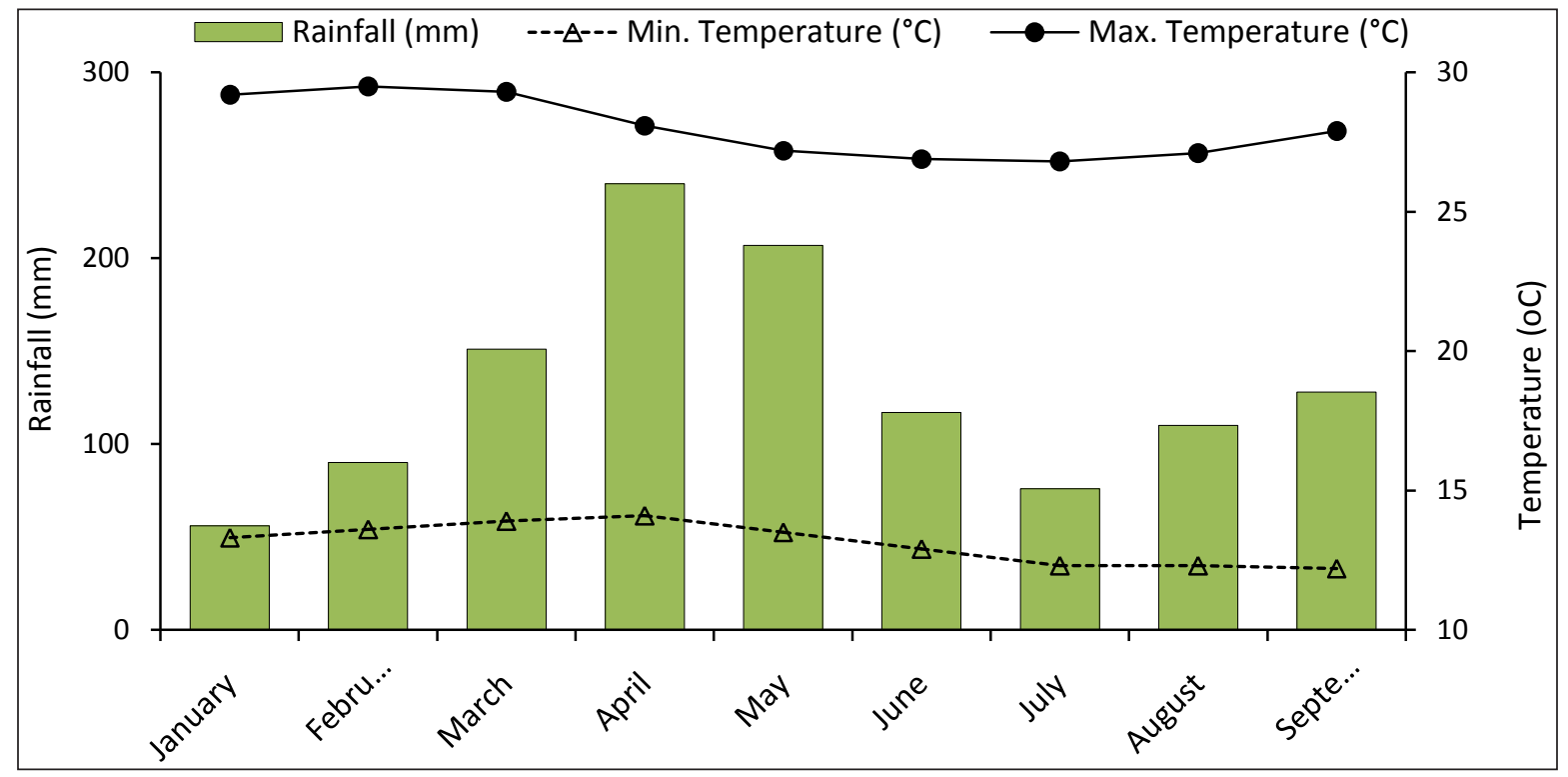

Fig. 1: Monthly rainfall and temperature across the two study sites in Rongo sub-county, Western Kenya (Source: Kenya Meteorological Department) 
Table 1: Initial soil physico-chemical properties of the experimental sites

\begin{tabular}{|c|c|c|c|c|c|c|c|c|c|c|c|c|c|}
\hline \multicolumn{8}{|c|}{ Physical properties } & \multicolumn{6}{|c|}{ Chemical properties } \\
\hline & \multicolumn{3}{|c|}{ Kambija } & \multicolumn{4}{|c|}{ Koderobara } & \multicolumn{3}{|c|}{ Kambija } & \multicolumn{3}{|c|}{ Koderobara } \\
\hline & 0-10 & $10-20$ & $20-30$ & 0-10 & $10-20$ & $20-30$ & & $0-10$ & $10-20$ & $20-30$ & $0-10$ & $10-20$ & $20-30$ \\
\hline \multicolumn{8}{|c|}{ (depth cm) } & \multicolumn{6}{|c|}{ (depth cm) } \\
\hline \multirow[t]{2}{*}{ Sandy (\%) } & 40 & 36 & 32 & 48 & 48 & 46 & $\mathrm{pH}$ (water) 1:2.5 & 6.6 & 6.24 & 5.92 & 5.44 & 5.15 & 5.83 \\
\hline & & & & & & & Organic C (\%) & 1.70 & 1.40 & 1.40 & 1.10 & 1.20 & 1.00 \\
\hline \multirow[t]{2}{*}{ Silt (\%) } & 18 & 12 & 20 & 6 & 8 & 4 & $\mathrm{P}\left(\mathrm{mg} \mathrm{kg}^{-1}\right)$ & 14.03 & 14.77 & 14.77 & 18.92 & 16.72 & 14.0 \\
\hline & & & & & & & $\mathrm{Mg}\left(\right.$ meq $\left.100 \mathrm{~g}^{-1}\right)$ & 12.31 & 11.22 & 10.76 & 5.28 & 5.54 & 5.22 \\
\hline \multirow[t]{2}{*}{ Clay (\%) } & 42 & 52 & 48 & 46 & 44 & 50 & $\mathrm{Ca}\left(\mathrm{meq} 100 \mathrm{~g}^{-1}\right)$ & 7.41 & 4.81 & 4.78 & 2.04 & 2.39 & 2.38 \\
\hline & & & & & & & $\mathrm{K}\left(\mathrm{meq} 100 \mathrm{~g}^{-1}\right)$ & 3.96 & 2.79 & 1.93 & 1.61 & 1.50 & 1.32 \\
\hline B.D $\left(\mathrm{g} \mathrm{cm}^{-3}\right)$ & 1.22 & 1.22 & 1.36 & 1.23 & 1.20 & 1.34 & $\mathrm{Na}\left(\mathrm{meq} 100 \mathrm{~g}^{-1}\right)$ & 0.74 & 0.79 & 0.60 & 1.94 & 0.55 & 0.56 \\
\hline \multirow[t]{2}{*}{ Texture } & SCL & SC & SCL & SC & SC & $\mathrm{SC}$ & $\mathrm{NO}_{3}\left(\mathrm{mg} \mathrm{kg}^{-1}\right)$ & 8.31 & 7.27 & 7.93 & 7.93 & 7.72 & 8.97 \\
\hline & & & & & & & $\mathrm{NH}_{4}\left(\mathrm{mg} \mathrm{kg}^{-1}\right)$ & 1.89 & 0.63 & 1.02 & 1.18 & 0.86 & 1.02 \\
\hline
\end{tabular}

B.D: Bulk density, SC: Sandy clay, SCL: Sandy clay loam.

Table 2: Maize yield, nitrogen efficacy indices: partial factor productivity (PFP), partial nitrogen balance (PNB), agronomic efficiency (N-AE), and nitrogen fertilizer recovery (NFR) as affected by nitrogen fertilizer

\begin{tabular}{|c|c|c|c|c|c|c|}
\hline Site & $\begin{array}{l}\text { Treatment } \\
\left(\mathbf{k g ~ h a}^{-1}\right)\end{array}$ & $\begin{array}{l}\text { Yield } \\
\left(\mathrm{kg} \mathrm{ha}^{-1}\right) \\
\end{array}$ & $\begin{array}{l}\text { PFP } \\
\left(\mathrm{kg} \mathrm{kg}^{-1}\right)\end{array}$ & $\begin{array}{l}\text { N-AE } \\
\left(\mathrm{kg} \mathrm{kg}^{-1}\right) \\
\end{array}$ & $\begin{array}{l}\text { PNB } \\
\left(\mathrm{g} \mathrm{kg}^{-1}\right) \\
\end{array}$ & $\begin{array}{l}\text { NFR } \\
(\%)\end{array}$ \\
\hline \multirow[t]{6}{*}{ Kambija } & No & $1298^{c}$ & - & - & - & - \\
\hline & N25 & $2294^{\mathrm{b}}$ & $23.84^{\mathrm{a}}$ & $20.51^{\mathrm{ab}}$ & $3.30^{\mathrm{a}}$ & $0.8^{\mathrm{b}}$ \\
\hline & N50 & $3416^{a}$ & $17.76^{\mathrm{b}}$ & $22.01^{a}$ & $2.53^{\mathrm{ab}}$ & $1.2^{\mathrm{a}}$ \\
\hline & N75 & $3030^{\mathrm{a}}$ & $10.50^{c}$ & $12.0^{\mathrm{b}}$ & $1.3^{\mathrm{b}}$ & $0.4^{\mathrm{c}}$ \\
\hline & $p$ value & $<0.001$ & $<0.001$ & $<0.001$ & $<0.001$ & 0.007 \\
\hline & $\mathrm{LSD}_{005}$ & 707.4 & 2.22 & 1.21 & 0.61 & 0.63 \\
\hline \multirow[t]{6}{*}{ Koderobara } & N0 & $1133^{b}$ & - & - & - & - \\
\hline & $\mathrm{N} 25$ & $1740^{\text {bc }}$ & $18.08^{\mathrm{ab}}$ & $12.5^{\mathrm{b}}$ & $1.6^{\mathrm{ab}}$ & $1.15^{\mathrm{b}}$ \\
\hline & N50 & $4348^{a}$ & $22.61^{a}$ & $33.41^{a}$ & $4.2^{\mathrm{a}}$ & $4.0^{\mathrm{a}}$ \\
\hline & N75 & $1759^{\mathrm{b}}$ & $6.09^{\mathrm{b}}$ & $4.3^{c}$ & $0.6^{\mathrm{b}}$ & $0.5^{c}$ \\
\hline & $p$ value & $<0.001$ & $<0.001$ & $<0.001$ & $<0.001$ & $<0.001$ \\
\hline & $\mathrm{LSD}_{005}$ & 1646.2 & 0.45 & 0.78 & 0.38 & 0.40 \\
\hline
\end{tabular}

Means followed by the same superscript letter within a column are not significantly different $(p \leq 0.05)$ by protected LSD test.

\section{Total nitrogen content in plant tissues as} affected by nitrogen fertilizer application

Varying $\mathrm{N}$ fertilizer rates to maize had a significant $(p<0.05)$ influence on $\mathrm{N}$ content at heading and maturity stages but not at seedling stage (Fig. 2). At heading stage, $\mathrm{N}$ uptake increased with increasing $\mathrm{N}$ application with the highest value $\left(21 \mathrm{~g} \mathrm{~kg}^{-1}\right)$ in Kambija, recorded in plots receiving $75 \mathrm{~kg} \mathrm{ha}^{-1}$ whereas in Koderobara, the highest value was $20 \mathrm{~g}$ $\mathrm{kg}^{-1}$ and it was observed in treatment where $\mathrm{N}$ was applied at a rate of $50 \mathrm{~kg} \mathrm{~N}^{-1}$. A similar trend was observed for $\mathrm{N}$ content in maize stalks and grains where $\mathrm{N}$ uptake increased with increasing $\mathrm{N}$ application up to a rate of $50 \mathrm{~kg} \mathrm{~N} \mathrm{ha}^{-1}$ after which a decrease was recorded.

\section{Maize yield and nitrogen efficacy as affected by nitrogen fertilizer application}

Maize yield and all NUE parameters: PFP, PNB, $\mathrm{N}-\mathrm{AE}$ and NFR were significantly $(p<0.05)$ affected by different $\mathrm{N}$ fertilizer application rates (Table $2)$. The highest grain yields recorded in Kambija $\left(3.4 \mathrm{t} \mathrm{ha}^{-1}\right)$ and in Koderobara $\left(4.3 \mathrm{t} \mathrm{ha}^{-1}\right)$ were due to $\mathrm{N}$ application at $50 \mathrm{~kg} \mathrm{~N}$ ha-1 and they were 62 and $74 \%$ higher, respectively than the unfertilized plots. Generally, PFP decreased with increasing $\mathrm{N}$ application with the highest values of 23.8 and $22.6 \mathrm{~kg} \mathrm{~kg}^{-1}$ recorded for Kambija and Koderobara, respectively. N-AE and NFR were significantly highest in the plots treated with $50 \mathrm{~kg} \mathrm{~N} \mathrm{ha}^{-1}$ and lowest in those receiving $75 \mathrm{~kg} \mathrm{~N}$ ha $^{-1}$ whereas with 


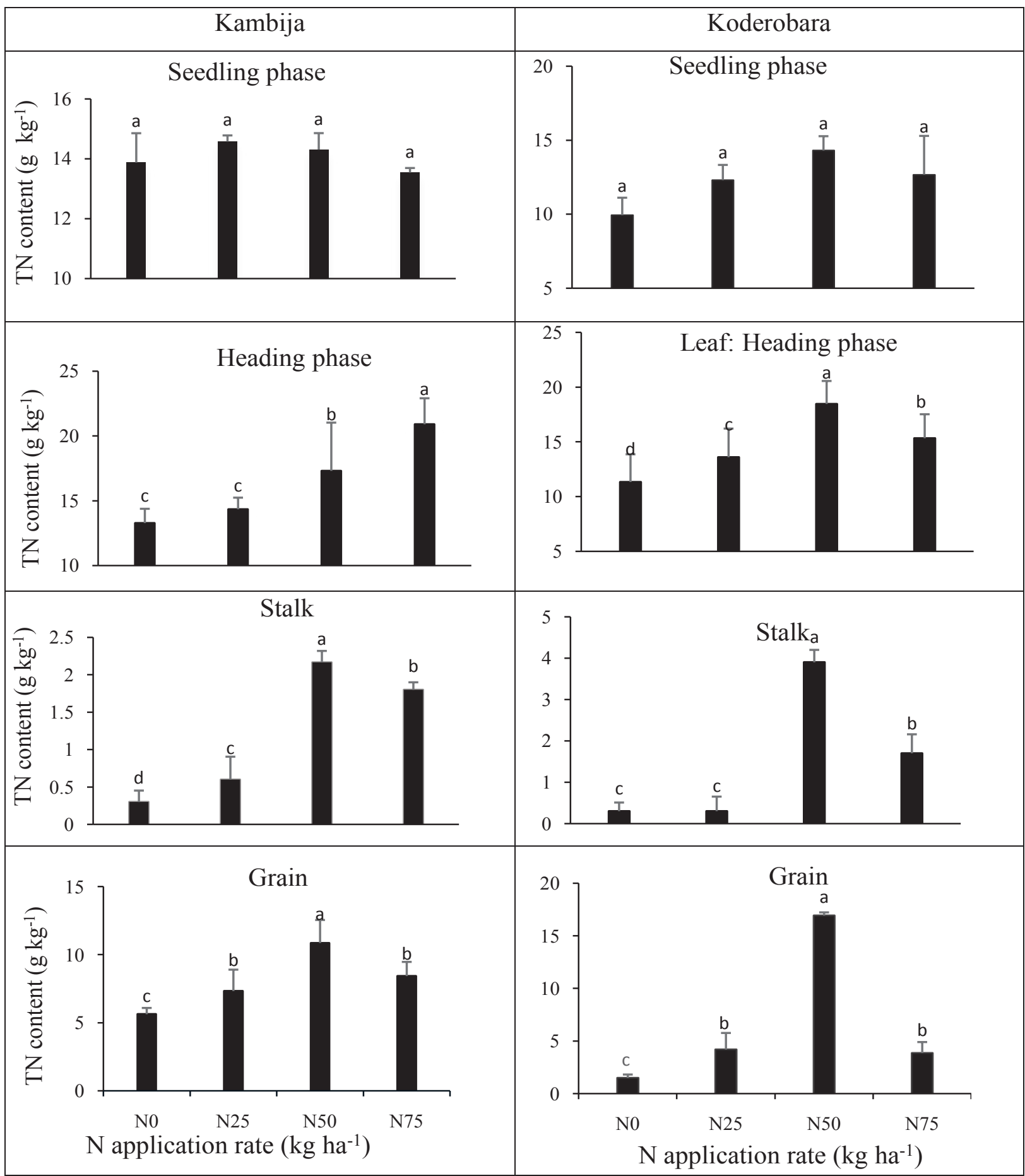

Fig. 2: Total N content in plant tissues (for leaf at seedling and heading stages; stalk and grain at maturity stage) as affected by applied $\mathrm{N}$ fertilizer rates in Kambija and Koderobara. Bars with the same letter show means that are not significantly different at $\mathrm{p} \leq 0.05$

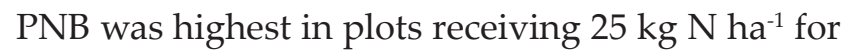

Kambija and at $50 \mathrm{~kg} \mathrm{ha}^{-1}$ for Koderobara.

\section{Relationships between maize yield and total $\mathbf{N}$ content in various plant growth stages}

Regression analysis of maize grain yield against total $\mathrm{N}$ content in the plant tissues (Leaf, stalk and grain) plant growth stage (Fig. 3). For instance, regressing yield against total $\mathrm{N}$ at seedling stage resulted in week coefficients of determination $\left(R^{2}<0.25\right)$ for both Kambija and Koderobara sites. Irrespective of study site, higher values of coefficients of determination ranging from 0.72 and 0.92 were 


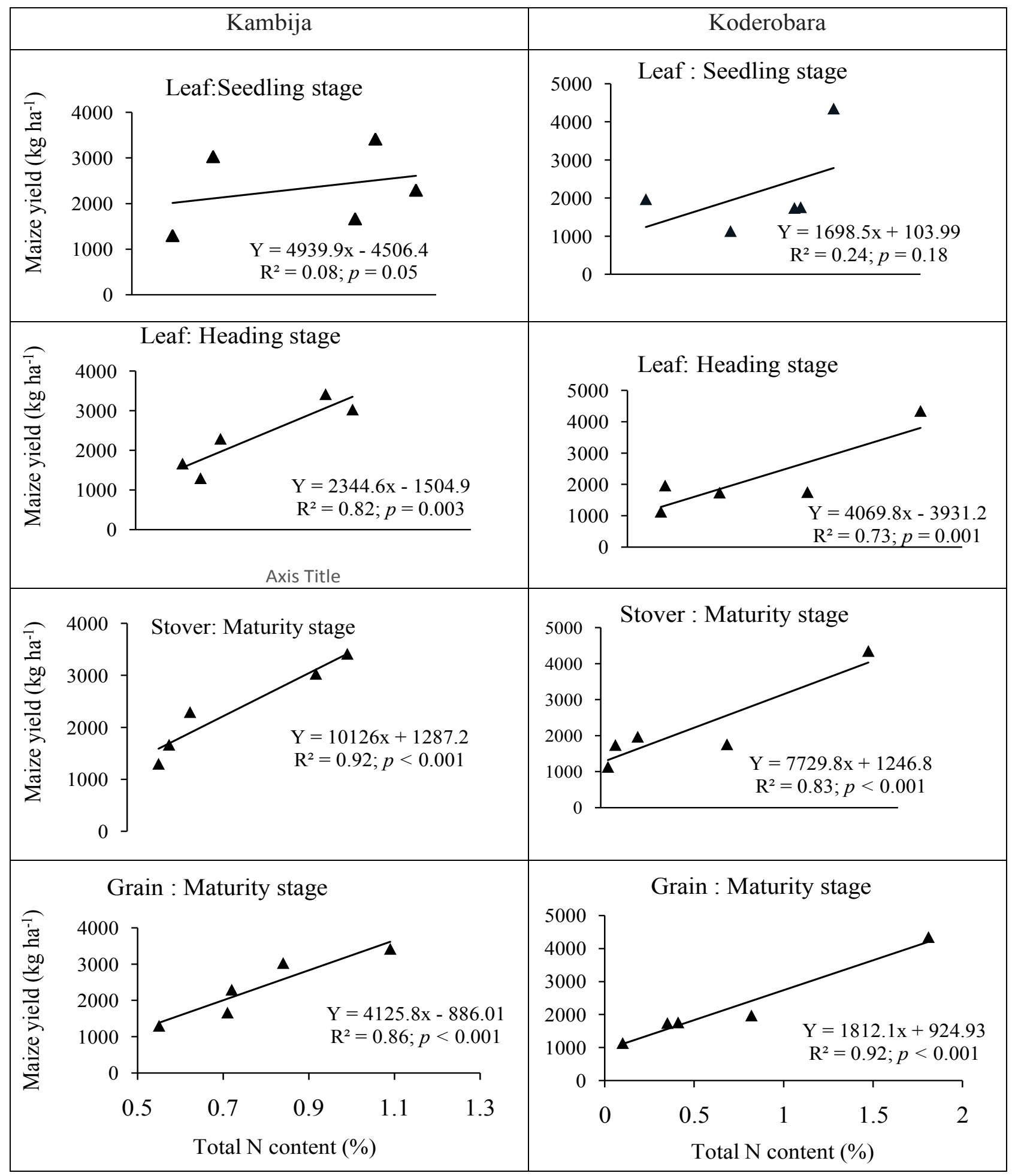

Fig. 3: Relationship between total $\mathrm{N}$ content in the plant tissues and maize yield

recorded when yield was regressed against total $\mathrm{N}$ at heading and maturity stages.

\section{Maize yield response}

Results showed that there was an increase in maize yield due to $\mathrm{N}$ fertilizer application in both experimental sites and the yield was highest with application of $50 \mathrm{~kg} \mathrm{~N} \mathrm{ha}^{-1}$ (Table 2). The increased maize yields in the fertilized plots at $\left(50 \mathrm{~kg} \mathrm{~N} \mathrm{ha}^{-1}\right)$ was $62 \%$ compared to the control at Kambija while at Koderobara, it increased by $74 \%$ compared to unfertilized plots. However, $\mathrm{N}$ fertilizer application 
over $50 \mathrm{~kg} \mathrm{~N} \mathrm{ha}^{-1}$ showed a decline of maize crop yields across all experimental sites. One option to get productivity gains is to apply the appropriate fertilizer rate inputs and at right time (Morris et al. 2007). The results illustrated that application of $50 \mathrm{~kg} \mathrm{~N} \mathrm{ha}^{-1}$ presented a reasonable threshold rate of $\mathrm{N}$ fertilizer in Rongo. Although, the probability of dispersion of maize yield differences revealed a perception of the distribution risks related to the use of $\mathrm{N}$ fertilizer. Hence, at Koderobara the risks of maize yield being less than the control were significantly high with $\mathrm{N}$ rates $>50 \mathrm{~kg} \mathrm{~N}$ ha ${ }^{1}$. The overall mean maize yields with $\mathrm{N}$ fertilizer application at Kambija was $2.5 \mathrm{t} \mathrm{ha}^{-1}$ compared to $2.2 \mathrm{t} \mathrm{ha}^{-1}$ at Koderobara. The present difference of maize yields between the two sites could be justified by variations in soil properties and previous inappropriate soil management systems (over cropping without soil replenishment, overusing mono-cropping system and insufficient inorganic fertilizer use).

Maize has a poor tolerance of overloading soil water in the early growth phase (Dar 2018). As N is the most dynamic macronutrient and sensitive to water flooding, so that there was high precipitation from the early growing phase to the flowering phase (63\% increase of plant $\mathrm{N}$ uptake) which may have affected potential maize production (Fageria, 2016). The observed worsening of soil degradation (e.g. soil acidity), may have affected maize yield response particularly at Koderobara where soil was more acidic. Worth noting is that some plots at Koderobara site was at one moment flooded due to heavy rains and this could have affected yields at that site. Required crop yield increase would be satisfied by improved sustainable cropping intensification system, which would elevate the need for agricultural inputs and its adequate utilization (Rockström et al. 2017). Without opposing the role of maize as staple food in SSA countries, current maize production level is low and far below agro-ecological potential for various maize yield milieus (Akossou, 2016). On different levels, the mean maize yields between 2003 and 2007 were $1.6 \mathrm{t} \mathrm{ha}^{-1}$ in Western Africa, $1.3 \mathrm{t} \mathrm{ha}^{-1}$ in East Africa, and $2.9 \mathrm{t} \mathrm{ha}^{-1}$ in Southern Africa (Jama et al. 2017). According to Kihara et al. (2016) and Gitari et al. (2015), low maize production thresholds are due to insufficient external nutrient inputs (particularly
N, P and K), challenges of soil chemical (e.g. soil acidity), soil physical (soil crusting, till layers), suboptimal rainfall amount or drought, unavailable improved seeds, pests and /or diseases.

\section{Nitrogen content in the various plant tissues}

Kambija site exhibited the highest $\mathrm{N}$ content in various plant tissues compared to Koderobara site. Therefore, $\mathrm{N}$ content at the seedling stage at both sites was lower compared to the heading phase due to poor rooting development, which is accountable in soil nutrient uptake by plants (Gitari et al. 2018; Fageria et al. 2005). The flooding that was experienced especially at Koderobara site could have resulted in $\mathrm{N}$ losses through leaching, denitrification and volatilization. Leaching and denitrification are due to excess rainfall and results in a decrease in $\mathrm{NO}_{3}-\mathrm{N}$ uptake from the soil. Like other livings biota, soil microorganisms need Oxygen for development. Hence, perhaps there was insufficient oxygen $\left(\mathrm{O}_{2}\right)$ in the soil during two first months of the experiment prompting the microorganisms to convert nitrate $\left(\mathrm{NO}_{3}^{-}\right)$ions into gaseous forms: nitric oxide (NO) and nitrous oxide $\left(\mathrm{N}_{2} \mathrm{O}\right)$ both of which are not available $\mathrm{N}$ forms for plant roots uptake. This process is named "denitrification" as biochemical process by which facultative bacteria use nitrate and nitrite in the absence of Oxygen when the soil is poorly drained with excessive rainfall (Cao et al. 2017). At heading phase, there was a slight elevation of $\mathrm{N}$ content in the flag leaves. This is the period when the cobs are at milking formation and therefore could require more nutrients to make it.

At maturity stage, the maize stalks had low $\mathrm{N}$ content compared to that in the maize grains. This could be due to storage of nutrients in grains while stalks act as transitory way of nutrients to the grains. Garcia et al. (2018) confirmed thattrading as Taylor \& Francis Group Blends of controlled-release urea (CRU N content decreased gradually in different plant tissues until 75 days after planting while it increased during the physiological maturity. Kuan et al. (2016) shared this idea reporting that the first stock of $\mathrm{N}$ content during maize growth found generally in the leaves and stems, but $\mathrm{N}$ content was translocated and accumulated in maize grains at physiological maturity. 
On the contrary, Riziki (2014) observed a continuous decline of $\mathrm{N}$ content in plant tissues from seedling stage to heading stage but with a slight increase in the grains in relation to the stalks. Brevik et al. (2015) pointed out that the crop uptake is often influenced by climate conditions and soil characteristics. Lack of soil aeration (Anaerobic condition) and deficient of nutrients among others might limit the access to nutrients by plant roots (Bak et al. 2016). Chomba et al. (2013) argued that the rates of nutrient uptake depend on the type of crop particularly during the maximum crop growth and varied with crop growth phases.

According to Chen et al. (2014), the major challenge in use of $\mathrm{N}$ fertilizer by plants is a low amount of applied $\mathrm{N}$ and time of the application to optimize $\mathrm{N}$ uptake and maize grain yields. A period of 6 to 8 weeks after planting in Wisconsin was a right time for $\mathrm{N}$ application to maize as realized by an increase of maize grain and tissue yield per unit N fertilizer used (Mueller et al., 2017). Maize grain may develop due to both remobilized $\mathrm{N}$ in the leaf and stalk and pursued $\mathrm{N}$ uptake from the soil. However, assuming that a split, season long $\mathrm{N}$ supply is crucial approach for crop production.

\subsection{Nitrogen use efficiency}

The results of this study indicated that NUE expressed as PFP decreased significantly with increasing amount of $\mathrm{N}$ fertilizer (Table 2). Particularly, the plots fertilized with $75 \mathrm{~kg} \mathrm{~N} \mathrm{ha}^{-1}$ recorded the lowest NUE (10.50 and 6.09) while those fertilized with $25 \mathrm{~kg} \mathrm{~N}^{-1}$ exhibited NUE (23.84 and 18.08) respectively at Kambija and Koderobara sites. This is in line with other findings by Thind et al. (2018) who reported that the NUE decreased significantly with increasing amount of $\mathrm{N}$ fertilizer. Manal and Aly (2008) reported that the ability to use $\mathrm{N}$ as determined by NUE, grain yield response was optimum at $45 \mathrm{~kg} \mathrm{~N} \mathrm{ha-1}$. Elemo (1997) agreed with these results reporting that yield raised by $200 \%$ over the control at $40 \mathrm{~kg}$ $\mathrm{N}$ ha ${ }^{-1}$ in two maize varieties of different maturity periods in the northern Guinea savannah of Nigeria. Kogbe and Adediran (2003) also reported that maize varieties produced well with $\mathrm{N}$ application over $3 \mathrm{t} \mathrm{ha}^{-1}$ of grain yield by using $50 \mathrm{~kg} \mathrm{~N} \mathrm{ha}^{-1}$. In addition, Kaizzi et al. (2012) pointed out that when $\mathrm{N}$ fertilizer was applied at a large amount than the recommended rate, it increases biomass level and enhance soil organic carbon, but NUE decreased. Soil nutrient management practices are concerned mainly with the effectiveness of applied inputs and reserving them in the field, so they can serve the next season cropping while preserving environmental contamination. This effectiveness in nutrient management focuses on maximizing $4 \mathrm{R}$ nutrient stewardship in using Right nutrient source to apply at the Right amount of nutrients in the Right Place and at the Right time (IFA 2009). As long as this practice is linked to conservational systems such as use of cover crops, fallow and continuous no-till, it will improve crop yields and renew soil fertility and reduce nutrients losses (Fixen, 2015).

Low grain production per unit of mineral $\mathrm{N}$ in the soil could be due to the error of $\mathrm{N}$ fertilizer application. This is mostly due to unfordable cost of $\mathrm{N}$ fertilizer especially on the majority of poor farmers. Agricultural management system gets success when accurate estimation of $\mathrm{N}$ rate has been made and when it generates a sufficient crop response (Altieri 2018). As a result, the optimum output returns can be received by the farmer, normally it is known as economically optimum $\mathrm{N}$ rate (Boardman, 2017). After harvest, this study gave the average nitrogen agronomic efficiency (N-AE) values under $\mathrm{N}$ fertilizer application (18. $17 \mathrm{~kg} \mathrm{~kg} \mathrm{~N}^{-1}$ and $16.73 \mathrm{~kg} \mathrm{~kg} \mathrm{~N}^{-1}$ ) respectively from Kambija and Koderobara sites. According to Vanlauwe et al. (2011), the mean of N-AE value showed under farmer management was $19 \mathrm{~kg} \mathrm{~kg}$ $\mathrm{N}^{-1}$ ) which was near to the mean of N-AE (14 kg $\mathrm{kg} \mathrm{N}^{-1}$ ) produced in the Malawi fertilizer subsidy strategy. Farmer- managed inorganic fertilizer and agronomic efficiency of researcher performed 19 and $23 \mathrm{~kg} \mathrm{~kg} \mathrm{~N}^{-1}$ respectively.

As one of production efficiencies, productivity nitrogen balance (PNB) decreased with increase in $\mathrm{N}$ rate application at Kambija but $\mathrm{N}$ applied at 50 $\mathrm{kg} \mathrm{N}$ ha ${ }^{-1}$ gave high PNB (4.2 g. $\left.\mathrm{kg}^{-1}\right)$ at Koderobara. Based on this case, it may be illustrated that the lowest $\mathrm{N}$ rate application would respond the most efficient use of nutrients applied. However, as with low $\mathrm{N}$ fertilizer rates and high outputs, the $\mathrm{N}$ used came from soil reserves. Relevantly, where nutrients are taken up from organic or mineral in the soil, the decrease in soil reserves continuously, signifies lower soil productivity as well as declined soil health and system resilience. In both sites, $\mathrm{N}$ 
fertilizer application at $50 \mathrm{~kg} \mathrm{~N} \mathrm{ha}^{-1}$ presented a high nitrogen fertilizer recovery (NFR) $(1.2 \%$ and $4.0 \%$ ) compared to other treatments. NFR indicated the amount of the applied $\mathrm{N}$ taken up by maize plant. The values for PNB and NFR below 1.0 can be compatible with an efficient cropping system, given that the $\mathrm{N}$ is maintained in the soil from season to season in an available form. In general, NUE improvement should always be carefully assessed in the context of keeping the effectiveness of the nutrients application in order to maintain the efficiency of the crop management practices (Hirel, 2011).

\section{CONCLUSION}

Maize grain yield increased by $62 \%$ and $74 \%$ with

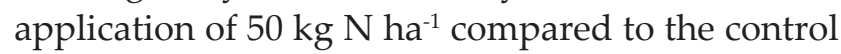
respectively at Kambija and Koderobara, justifying that $\mathrm{N}$ fertilizer use significantly increases maize yield. This implies that maize grain yields, $\mathrm{N}$ content and NUE are not necessarily increased with high rates of fertilizer application. Based on the findings of this study, application of $\mathrm{N}$ fertilizer at right amount ( $50 \mathrm{~kg} \mathrm{~N} \mathrm{ha}^{-1}$ ) could be a profitable approach to improve $\mathrm{N}$ uptake, optimize nitrogen use efficiency and definitely maize yield while minimizing environmental pollution. It is imperative to have such information reach the farmers who would benefit by boosting their maize production with minimal cost on fertilizers.

\section{REFERENCES}

1. Adenle, A., Azadi, H. and Manning, L. 2018. The era of sustainable agricultural development In Africa: Understanding the benefits and constraints. Food Reviews International, 34(5): 411-433.

2. Akossou, A.Y., Attakpa, E.Y., Fonton, N.H., Sinsin, B. and Bosma, R.H. 2016. Spatial and temporal analysis of maize (Zea mays) crop yields in Benin from 1987 to 2007. Agricultural and Forest Meteorology, 220: 177-189.

3. Albert, B., Le, Cahérec, F., Niogret, M.F., Faes, P., Avice, J.C., Leport, L. and Bouchereau, A. 2012. Nitrogen availability impacts oilseed rape (Brassica napus L.) plant water status and proline production efficiency under water-limited conditions. Planta, 236(2): 659-676.

4. Ali, J., Bakht, J., Shafi, M., Khan, S. and Ali, W. 2002. Uptake of nitrogen as affected by a various combination of nitrogen and phosphorous. Asian Journal of Plant Sciences, 1: 367-369.

5. Altieri, M.A. 2018. Agroecology: the science of sustainable agriculture. CRC Press.
6. Bak, K., Gaj, R. and Budka, A. 2016. Accumulation of nitrogen, phosphorus and potassium in mature maize under variable rates of mineral fertilization, Fragmenta Agronomica, 33(1): 7-19.

7. Boardman, A.E., Greenberg, D.H., Vining, A.R. and Weimer, D.L. 2017. Cost-benefit analysis: concepts and practice. Cambridge University Press.

8. Bremner, J.M. 1996. Nitrogen total. In: Sparks, D.L., Page, A.L., Helmke, P.A., Loeppert, R.H., Soltanpour, P.N., Tabatabai, M.A., Johnston, C.T. and Sumner, M.E. (Eds.), Methods of Soil Analysis, Part 3: Chemical Methods. Soil Science Society of America, Inc. American Society of Agronomy, Inc., Madison, WI, pp. 1085-1121.

9. Brevik, E.C., Cerdà, A., Mataix-Solera, J., Pereg, L., Quinton, J.N., Six, J. and Van, Oost, K. 2015. The interdisciplinary nature of soil. Soil, 1(1): 117-129.

10. Cao, W., Guan, Q., Li, Y., Wang, M. and Liu, B. 2017. The contribution of denitrification and anaerobic ammonium oxidation to $\mathrm{N}_{2}$ production in mangrove sediments in Southeast China. Journal of Soils and Sediments, 17(6): 1767-1776.

11. Chen, X., Cui, Z, Fan, M., Vitousek, P., Zhao, M., Ma, W. and Deng, X. 2014. Producing more grain with lower environmental costs. Nature, 514(7523): 486.

12. Chomba, S.K., Okalebo, J.R., Imo, M., Mutuo, P.K. and Walsh, M.G. 2013. Predicting maize response to fertilizer application using growth curves in western Kenya. Global Journal of Arable Crop Production, 1(1): 78-85.

13. Dar, Z.M., Masood, A., Mughal, A.H., Asif, M. and Malik, M.A. 2018. Review on Drought Tolerance in Plants Induced by Plant Growth Promoting Rhizobacteria. Journal homepage: http://www. Ijcmas.com, 7(05).

14. Elemo, K.A. 1997. Extra-early and early maize varieties as affected by rate and time of nitrogen fertilization. In: Contribution of food self-sufficiency: Maize research and development in West and Central Africa. Proceedings of a regional maize workshop, IITA, Cotonou, Benin Republic, pp. 241-246.

15. Fageria, N.K. and Baligar, V.C. 2005. Enhancing nitrogen use efficiency in crop plants. Advances in Agronomy, 88: 97-185.

16. Fageria, N.K. 2016. The use of nutrients in crop plants. CRC press.

17. Fixen, P.E., Brentrup, T., Bruulsema, F., Garcia, R., Norton, S. and Zingore. 2015. Nutrient/Fertilizer Use Efficiency: Measurement, Current Situation and Trends. In: P. Drechsel, P. Heffer, H. Magen, R. Mikkelsen, D. Wichelns. (Eds.). Managing Water and Fertilizer for Sustainable Agricultural Intensification. International Fertilizer Industry Association (IFA), International, Water Management Institute (IWMI), International Plant Nutrition Institute (IPNI), and International Potash Institute (IPI). Paris, France, pp. 8- 37.

18. Garcia, P.L., González-Villalba, H.A., Sermarini, R.A. and Trivelin, P.C. 2018. Nitrogen use efficiency and nutrient partitioning in maize as affected by blends of controlled- 
release and conventional urea. Archives of Agronomy and Soil Science, 64(14): 1944-1962.

19. Gitari, H.I., Karanja, N.N., Gachene, C.K.K., Kamau, S., Sharma, K. and Schulte-Geldermann, E. 2018. Nitrogen and phosphorous uptake by potato (Solanum tuberosum L.) and their use efficiency under potato-legume intercropping systems. Field Crop Research, 222: 78-84.

20. Gitari, H.I., Mochoge, B.E. and Danga, B.O. 2015. Effect of lime and goat manure on soil acidity and maize (Zea mays) growth parameters at Kavutiri, Embu County Central Kenya. Journal of Soil Science and Environmental Management, 6: 275-283.

21. Gitari, H.I., Gachene, C.K.K., Karanja NN, Kamau S, Nyawade SO, Schulte-Geldermann E. 2019. Potato-legume intercropping on a sloping terrain and its effects on soil physico-chemical properties. Plant and Soil, 438: 447-460.

22. Hassan, M.J., Raza, M.A., Rehman, S.U., Ansar, M., Gitari, H., Khan, I., Wajid, M., Ahmed, M., Shah, G.A., Peng, Y., Li, Z. 2020. Effect of cadmium toxicity on growth, oxidative damage, antioxidant defense system and cadmium accumulation in two sorghum cultivars. Plants. 9(11): 1575.

23. Hirel, B., Tétu, T., Lea, P.J. and Dubois, F. 2011. Improving nitrogen use efficiency in crops for sustainable agriculture. Sustainability, 3(9): 1452-1485.

24. Hodge, A., Robinson, D. and Fitter, A. 2000. Are microorganisms more effective than plants at competing for nitrogen? Trends in Plant Science, 5(7): 304-308.

25. IFA-international Fertilizer Association. 2009. The Global " $4 \mathrm{R}$ " Nutrient Stewardship Framework for Developing and Delivering Fertilizer Best Management Practices. International Fertilizer Industry Association (IFA), Paris, France.

26. Jama, B., Kimani, D., Harawa, R., Mavuthu, A.K. and Sileshi, G.W. 2017. Maize yield response, nitrogen use efficiency and financial returns to fertilizer on smallholder farms in southern Africa. Food Security, 9(3): 577-593.

27. Kaizzi, K.C., Byalebeka, J., Semalulu, O., Alou, I., Zimwanguyizza, W., Nansamba, A. and Wortmann, C.S. 2012. Maize response to fertilizer and nitrogen use efficiency in Uganda. Agronomy Journal, 104(1): 73-82.

28. Kihara, J., Nziguheba, G., Zingore, S., Coulibaly, A., Esilaba, A., Kabambe, V., Njoroge, S., Palm, C. and Huising, J. 2016. Understanding variability in crop response to fertilizer and amendments in sub-Saharan Africa. Agriculture, Ecosystems \& Environment, 229: 1-12.

29. Kogbe, J.O.S. and Adediran, J.A. 2003. Influence of nitrogen, phosphorus and potassium application on the yield of maize in the savanna zone of Nigeria. African Journal of Biotechnology, 2(10): 345-349.

30. Kuan, K.B., Othman, R., Rahim, K.A. and Shamsuddin, Z.H. 2016. Plant growth- promoting rhizobacteria inoculation to enhance vegetative growth, nitrogen fixation and nitrogen remobilization of maize under greenhouse conditions. PLoS One, 11(3): e0152478.
31. Lásztity R. 1998. Oat grain a wonderful reservoir of natural nutrients and biologically active substances. Food Reviews International, 14(1): 99-119.

32. Maitra, S., Hossain, A., Brestic, M., Skalicky, M., Ondrisik, P., Gitari, H., Brahmachari, K., Shankar, T., Bhadra, P., Palai, J.B., Jena, J., Bhattacharya, U., Duvvada, S.K., Lalichetti, S. and Sairam, M. 2020. Intercropping system - A low input agricultural strategy for food and environmental security. Agronomy, 11(2): 343.

33. Manal, H.M. and Aly, A.A. 2008. Yielding ability and nitrogen use efficiency in maize inbred lines and their crosses. International Journal of Agricultural Research, 3: 27-39.

34. Midega, C.A., Bruce, T.J., Pickett, J.A., Pittchar, J.O., Murage, A. and Khan, Z.R. 2015. Climate-adapted companion cropping increases agricultural productivity in East Africa. Field Crops Research, 180: 118-125.

35. Morris, M., Kelly, V.A., Kopicki, R.J. and Byerlee, D. 2007. Fertilizer use in African agriculture: Lessons learned and good practice guidelines. The World Bank.

36. Mueller, S.M., Camberato, J.J., Messina, C., Shanahan, J., Zhang, H. and Vyn, T.J. 2017. Late-split nitrogen applications increased maize plant nitrogen recovery but not yield under moderate to high nitrogen rates. Agronomy Journal, 109(6): 2689-2699.

37. Nunes, G.H.S., Silva, P.S.L. and Nunes, S.G.H. 1996. Response of maize to nitrogen levels and weeds control. Ciencia-e-Agrotecnologia, 20: 205-211.

38. Nyawade, S.O., Gachene, C.K.K., Karanja, N.N., Gitari, H.I., Schulte-Geldermann, E. and Parker, M. 2019. Controlling soil erosion in smallholder potato farming systems using legume intercrops. Geoderma Regional, 17: e00225.

39. Nyawade, S.O., Karanja, N.N., Gachene, C.K.K., Gitari, H.I., Schulte-Geldermann, E. and Parker, M. 2020. Optimizing soil nitrogen balance in a potato cropping system through legume intercropping. Nutrient Cycling in Agroecosystems, 117: 43-59.

40. Okalebo, J.G., Ojiem, J, Batiano, A and Mudeheri, M. 2002. Laboratory methods of soil and plant analysis. A working manual, $2^{\text {nd }}$ edition, TSBF-CIAT, SSSEA, KARI, Sacred Africa, Moi University, pp.128.

41. Onyango, A.O. 2016. Finger millet: food security crop in the arid and semi-arid lands (ASALs) of Kenya. World Environment, 6(2): 62-70.

42. Rao, E.J.O., Midega, C., Atieno, F., Auma, J.O., Cadilhon, J.J., Mango, N. and Wesonga, M. 2015. A situational analysis of agricultural production and marketing, and natural resources management systems in West Kenya.

43. Riziki, U.M. 2014. Improving sorghum grain yields through use of mineral fertilizers and farmyard manure for smallholder farmers in Makueni and Machakos Counties. MSc thesis, School of Agriculture and Enterprise Development, Kenyatta University.

44. Rockström, J., Williams, J., Daily, G., Noble, A., Matthews, N., Gordon, L. and de Fraiture C. 2017. Sustainable 
intensification of agriculture for human prosperity and global sustainability. Ambio, 46(1): 4-17.

45. Roy, R.N., Finck, A., Blair, G.J. and Tandon, H.L.S. 2006. Plant nutrition for food security. A guide for integrated nutrient management. FAO Fertilizer and Plant Nutrition Bulletin, 16: 368.

46. Sanchez, P.A. 2002. Soil fertility and hunger in Africa. Science, 295: 2019-2020.

47. Thind, H.S., Singh, Y., Sharma, S., Goyal, D., Singh, V. and Singh, B. 2018. Optimal rate and schedule of nitrogen fertilizer application for enhanced. yield and nitrogen use efficiency in dry-seeded rice in north-western India. Archives of Agronomy and Soil Science, 64(2): 196-207.
48. Van Ittersum, M.K., Van Bussel, L.G., Wolf, J., Grassini, P., Van Wart, J., Guilpart, N. and Yang, H. 2016. Can sub-Saharan Africa feed itself? Proceedings of the National Academy of Sciences, 113(52): 14964-14969.

49. Vanlauwe, B., Kihara, J., Chivenge, P., Pypers, P., Coe, R. and Six, J. 2011. Agronomic use efficiency of N fertilizer in maize-based systems in sub-Saharan Africa within the context of integrated soil fertility management. Plant and Soil, 339(1-2): 35-50.

50. Wischmeier, W.H. and Mannering, J.V. 1969. Relation of soil properties to its erodibility 1. Soil Science Society of America Journal, 33(1): 131-137. 
